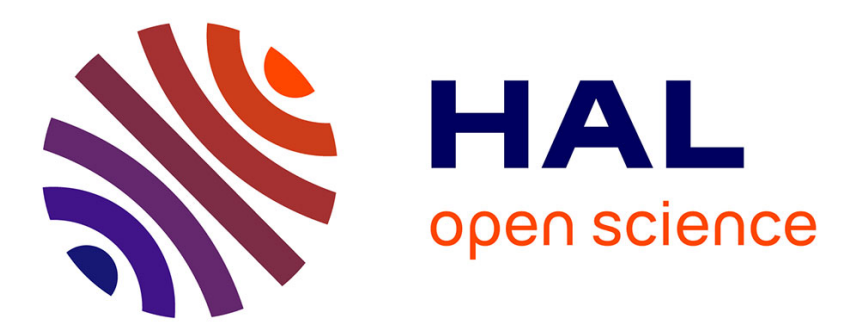

\title{
River management and habitat characteristics of three sympatric aquatic rodents: common muskrat, coypu and European beaver
}

Thomas Ruys, Olivier Lorvelec, Alain Marre, Ivan I. Bernez

\section{To cite this version:}

Thomas Ruys, Olivier Lorvelec, Alain Marre, Ivan I. Bernez. River management and habitat characteristics of three sympatric aquatic rodents: common muskrat, coypu and European beaver. European Journal of Wildlife Research, 2011, 57 (4), pp.851-864. 10.1007/s10344-011-0497-y . hal-00661561

\section{HAL Id: hal-00661561 https://hal.science/hal-00661561}

Submitted on 20 Jan 2012

HAL is a multi-disciplinary open access archive for the deposit and dissemination of scientific research documents, whether they are published or not. The documents may come from teaching and research institutions in France or abroad, or from public or private research centers.
L'archive ouverte pluridisciplinaire HAL, est destinée au dépôt et à la diffusion de documents scientifiques de niveau recherche, publiés ou non, émanant des établissements d'enseignement et de recherche français ou étrangers, des laboratoires publics ou privés. 


\title{
River management and habitat characteristics of three sympatric aquatic rodents: common muskrat, coypu and European beaver
}

\author{
Thomas Ruys • Olivier Lorvelec • Alain Marre • \\ Ivan Bernez
}

Received: 23 February 2009/Revised: 22 October 2010 / Accepted: 6 January 2011 /Published online: 20 January 2011

(C) Springer-Verlag 2011

\begin{abstract}
The ecological environment of three aquatic rodents was studied in the French Ardennes region. Two species, the coypu (Myocastor coypus) and the common muskrat (Ondatra zibethicus), are invasive. By contrast the native European beaver (Castor fiber) was extirpated from the region, subsequently reintroduced, and currently is protected. The aim of this study was to compare the ecological requirements of these three species and predict their future range distributions. We studied the relationship between the species and describe the characteristics of
\end{abstract}

Communicated by H. Kierdorf

T. Ruys $\cdot$ A. Marre

GEGENA, Université de Reims-Champagne-Ardenne

Campus Croix Rouge,

57 rue Pierre Taittinger,

51096 Reims Cedex, France

A.Marre

e-mail: alain.marre@univ-reims.fr

O. Lorvelec

INRA, UMR 985 Ecologie et santé des Ecosystèmes,

Equipe Ecologie des Invasions Biologiques,

Campus de Beaulieu,

35042 Rennes Cedex, France

e-mail: lorvelec@rennes.inra.fr

\section{Bernez}

INRA, UMR 985 Ecologie et santé des Ecosystèmes,

Equipe Ecologie et Sciences phytosanitaires,

65 rue de Saint-Brieuc, CS 84215 ,

35042 Rennes Cedex, France

e-mail: bernez@agrocampus-ouest.fr

\section{T. Ruys $(\square)$}

2C2A, Centre de Recherche et de Formation en Eco-Ethologie,

5 rue de la héronnière,

08240 Boult-aux-Bois, France

e-mail: thomasruys@wanadoo.fr waterways and riparian vegetation in 29 sampling sites. Coypus and muskrats were observed in a variety of riparian habitats and their probability of detection appeared to be independent of waterway width, bank height or bank slope. The availability of numerous herbaceous plants, known to be consumed by these species, may facilitate their settlement. Muskrats are widespread on the French Ardennes waterways, but coypus have not yet colonised the northern part of the region. On the other hand, the beaver was observed primarily in the widest waterways with high banks, where woody plant species, such as Betula, Carpinus and Fraxinus, are found in abundance. Potentially favourable sites for beaver and coypu settlement were analysed to suggest appropriate management according to each species' status. However, the number of sample sites is weak, especially for sites with beaver, limiting our conclusion.

Keywords Riparian ecosystem - Biological invasion . Aquatic rodent $\cdot$ Ecological management $\cdot$ Species requirement . French Ardennes

\section{Introduction}

Identifying species' requirements is a critical ingredient to developing sound management and conservation plans (South et al. 2000; Lorvelec and Pascal 2005; Parker 2008). Ecological niches are defined by the relationships between organisms and the physical and biological environments, taking into account both time and space (Shea and Chesson 2002). Native biological diversity can be threatened by nonnative organisms that expand beyond their previous range (i.e. 'biological invasion', Williamson 1996) and cause significant damage (i.e. 'invasive species', IUCN 1999). For example, invasive herbivores can significantly 
alter vegetation structure and ecosystem functions in recipient communities (Danilov 1992; Manchester and Bullock 2000; Vázquez 2002; Baldwin and Pendleton 2003). Invasive species may also represent novel competitors or predators of native species, and as such, they can significantly alter the multidimensional space of native species' niches (Shea and Chesson 2002). For example, there is no niche partitioning between the nonnative grey squirrel (Sciurus carolinensis) and the native Eurasian red squirrel (Sciurus vulgaris). As a result, both species compete for food when resources are limited (Wauters et al. 2002a) and European red squirrel experience a decrease in body mass and relative fitness (Wauters et al. 2002b). So there is always a link between biological invasions and interspecific competition (Valéry et al. 2008). Investigations into the niche of invasive species allows researchers not only to predict the habitats in which they are likely to settle but also to anticipate potential antagonistic interactions with native species (Mack et al. 2000; Kolar and Lodge 2001; Pascal et al. 2006). Such information can also inform restoration efforts, such as the return of the native European otter (Lutra lutra) in England that is significantly related to the decline of the introduced American mink (Mustela vison; McDonald et al. 2007).

The coypu (Myocastor coypus) and the common muskrat (Ondatra zibethicus) are originate from North and South America, respectively. Both species have been repeatedly introduced into multiple European countries (Willner et al. 1980; Carter and Leonard 2002). These two aquatic rodents modify wetland ecosystems through grazing and facilitate the establishment of invasive plant species by creating open areas (Johnson and Foote 1997; Higgins and Mitsch 2001; Prigioni et al. 2005). Their burrows lead to the collapse of river banks and dikes and can damage of crops (Allen and Hoffman 1984; Jouventin et al. 1996, Panzacchi et al. 2007). Moreover, the coypu is considered amongst the world's 100 worst invasive alien species (Lowe et al. 2000). For this reason, these two invasive species are considered as pests in countries where they have been introduced such as in France (Le Louarn and Quéré 2003). On the other hand, the European beaver (Castor fiber) is a native aquatic rodent to France. Only a few individuals survived in southern France at the end of the XIX (Rouland 1991) and this population served as a source for subsequent reintroduction efforts in the XX (Rouland 1991). Beavers were extirpating from the French Ardennes region, the XVII, due to hunting, but returned in the late 1990s through a nonofficial reintroduction in Belgium close to the French border. From 1998 to 2003, a Belgian association released 101 beavers (from Germany) into the Belgian - and possibly the FrenchArdennes region (Libois 2006). Beavers then recolonised the Ardennes region from North to South following the Meuse River, which flows through Belgium and France (Leau and
Léger 2006). In the same region, muskrat fur farms were present at the end of the 1920s. Both voluntary and accidental releases of muskrats resulted in the colonisation of the whole hydrographic system of the French Ardennes region from North to South over a period of 50 years (Pascal et al. 2006). Coypus arrived in the 1990s, following the Aisne River, a large river in the South of the Ardennes, and colonised in 20 years the whole region except for its northern part (Léger 2007).

Muskrats and coypus are officially classified as pests due to the damage they can cause (Le Louarn and Quéré 2003). The beaver is viewed as an ecosystem engineer and most scientists and land managers consider the species as a key component of the native riparian ecosystem. The species constructs dams, which create wetlands that increase the abundance of herbaceous plants and favours the reproduction of taxa such as dragonflies, amphibians and wildfowl (Wright et al. 2002; Rosell et al. 2005). For humans, the beaver can be considered a useful river manager because it maintains vegetation levels and therefore vegetation cover; the resulting wetlands serve as buffer areas that limit the impacts of flooding and pollution etc. (Baguette 1994; Müller-Schwarze and Sun 2003). However, an ecosystem engineer can also disrupt riparian ecological functions (Nolet and Rosell 1998). Beavers can be seen as problematic because they forage on woody tree species cultivated by man, such as poplar groves or orchards. Dam construction can also result in local flooding (Breck et al. 2003; Schwoerer et al. 2008). In southern South America, for example, the North American beaver (Castor canadensis) is considered an invasive ecosystem engineer. There, beavers can alter the velocity of streams, change the landscape from forests with Nothofagus to grass- and sedge-dominated meadows and construct dams that lead to increases in herbaceous species richness and also invasive plant species (Anderson et al. 2006, 2009). Consequently, the beaver can be seen as an ecosystem engineer, provided that it stays within its historical range. In such cases, reintroductions are compatible with habitat restoration. By contrast, beavers introduced outside of their native range can be seen as a source of habitat alteration. Coypus and muskrats are most certainly alien and invasive species in the French Ardennes region, but not the reintroduced beaver. During the process of colonisation in areas where it was formerly native, the European beaver probably overcame a reproductive filter, which subsequently allowed it to disperse. This was likely easier than overcoming all filters described by Richardson et al. (2000) for exotic plants. According to Colautti and MacIsaac (2004) and Valéry et al. (2008), invasive species populations have to be locally dominant. According to this definition, the European beaver is not an invasive species because the French Ardennes population is not locally dominant. It is simply in a spreading stage. Due to its historic brush with extinction, the European beaver is protected in France and classified in 
Appendices II and IV of the Directive 92/43/EEC of 21 May 1992 on the conservation of natural habitats and wild fauna and flora. The national redlist (IUCN and National Museum 2009, http://www.uicn.fr/IMG/pdf/Dossier_presse_Liste_rouge_mammiferes_de_metropole.pdf) considers the species of "least concern" (LC). The beaver is an essential component of French and European biodiversity. This reintroduction is not debated in France as in other countries (Macdonald et al. 1995).

French environmental managers have to reconcile the management of these three aquatic rodents: on one hand, a reintroduced and protected species; on the other hand, two alien and unwanted species (Table 1). This situation comes within a context of wildlife management and restoration in riparian ecology.

The spread of coypus and beavers is recent and ongoing. The early stages (Williamson 1996) have already occurred: these include the arrival of a species in a new locality and its success in establishing itself there as a viable population.
Here, we had the opportunity to study a contemporary invasion process. It could be useful to find sustainable solutions with an integrated ecological management program (De Nooij et al. 2004). The objectives of this study were to identify and compare ecological habitat characteristics of the three species. A better understanding of each species' environment might allow one to predict future range expansions, to favour beaver populations and to limit the spreading of coypus and muskrats.

\section{Study area}

The French Ardennes region ("Ardennes" hereafter; $5,246 \mathrm{~km}^{2} ; 40-50^{\circ} \mathrm{N}, 1.4-3.5^{\circ} \mathrm{E}$ ) is affected by oceanic and some continental influences (yearly average temperature $9^{\circ} \mathrm{C}$; annual rainfall $850 \mathrm{~mm}$; Fig. 1). It can be divided into three geomorphological areas and two hydrographic basins.

Table 1 General species requirements and status of the European beaver, the coypu and the common muskrat in native and introduced ranges, according to the literature

\begin{tabular}{|c|c|c|c|}
\hline & European beaver & Coypu & Common muskrat \\
\hline $\begin{array}{l}\text { Status in the French Ardennes } \\
\text { region (Le Louarn and Quéré } \\
\text { 2003) }\end{array}$ & $\begin{array}{l}\text { Native, vanished then reintroduced, } \\
\text { protected, Appendix III of the Bern } \\
\text { Convention, Appendices II and IV of } \\
\text { the EU Habitats and Species } \\
\text { Directives, national protection in } \\
\text { environmental code article L.411-1 } \\
\text { and L.411-2 }\end{array}$ & $\begin{array}{l}\text { Alien, invasive species, } \\
\text { game, hunted }\end{array}$ & $\begin{array}{l}\text { Alien, invasive species, game, } \\
\text { hunted }\end{array}$ \\
\hline \multicolumn{4}{|l|}{ Abiotic conditions } \\
\hline Habitat types & $\begin{array}{l}\text { First wide rivers, then other waterways, } \\
\text { ponds, lakes, gravel pit }\end{array}$ & \multicolumn{2}{|c|}{ Rivers, marshes, ponds, lakes, canals, draining ditches } \\
\hline Waterway gradient & Weak $(<6 \%)$ & Weak & Weak \\
\hline Water depth & Permanent $(>50 \mathrm{~cm})$ & Permanent & Permanent \\
\hline Water velocity & Weak & Weak & Weak $\left(<1 \mathrm{~m}^{3} \mathrm{~s}^{-1}\right)$ \\
\hline Soil & Clay & Clay & Clay \\
\hline Bank height & High & High & Mean \\
\hline Bank slope & High & High & High \\
\hline Lodge & Burrow, hut, natural cavity & Burrow, nest & Burrow hut \\
\hline \multicolumn{4}{|l|}{ Diet } \\
\hline Herbaceous & $\begin{array}{l}\text { Macrophyte (Achillea spp., Carex spp., } \\
\text { Ranunculus spp.) }+140 \text { taxa recorded }\end{array}$ & \multicolumn{2}{|c|}{ Macrophyte (Typha spp., Scirpus spp., Phragmites spp., etc.) } \\
\hline Aquatic & Elodea spp., Nuphar spp., etc. & \multicolumn{2}{|c|}{ Callitriche spp., Nuphar spp., Sparganium spp., etc. } \\
\hline Cultivation & Zea mays, Brassica spp., etc. & \multicolumn{2}{|c|}{ Z. mays, Brassica spp., Solanum spp., etc. } \\
\hline Woody & $\begin{array}{l}\text { Salix spp., Alnus spp., Populus spp., } \\
\text { Fraxinus spp., etc. }\end{array}$ & \multicolumn{2}{|l|}{ Salix spp., Populus spp. } \\
\hline Other components & - & Anodonta cygnea & Anodonta spp. \\
\hline References & $\begin{array}{l}\text { Blanchet 1977; Erôme 1982; Allen } \\
\text { 1983; Collen and Gibson 2001; } \\
\text { Fustec and Cormier } 2003 \text { Müller- } \\
\text { Schwarze and Sun } 2003\end{array}$ & $\begin{array}{l}\text { Swank and Petrides 1954; } \\
\text { Davis and Jenson 1960; } \\
\text { Woods et al. 1992; } \\
\text { Jouventin et al. 1996; } \\
\text { Borgnia et al. 2000; } \\
\text { Corriale et al. 2006 }\end{array}$ & $\begin{array}{l}\text { Errington 1963; Allen and } \\
\text { Hoffman 1984; Hanson et al. } \\
\text { 1989; Messier and Virgl 1992; } \\
\text { Clark 1994; Nadeau et al. 1995 }\end{array}$ \\
\hline
\end{tabular}




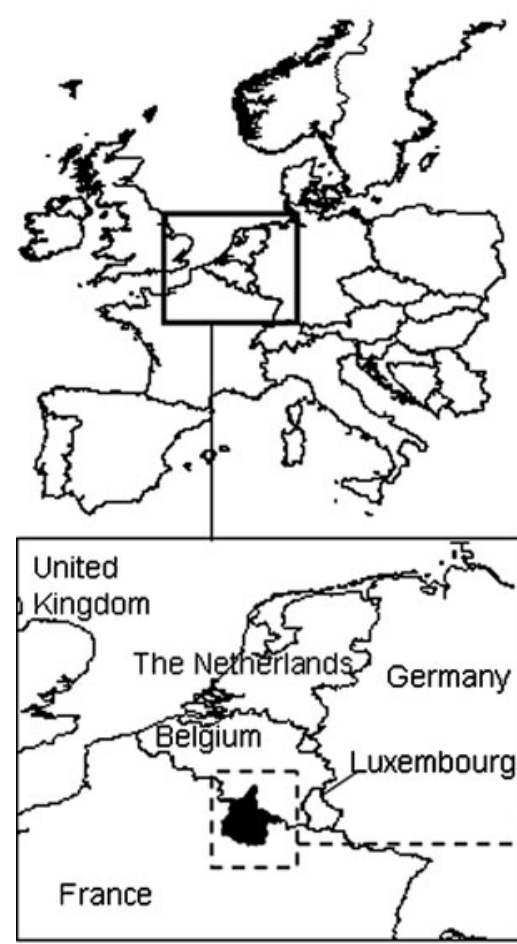

The French Ardennes Region

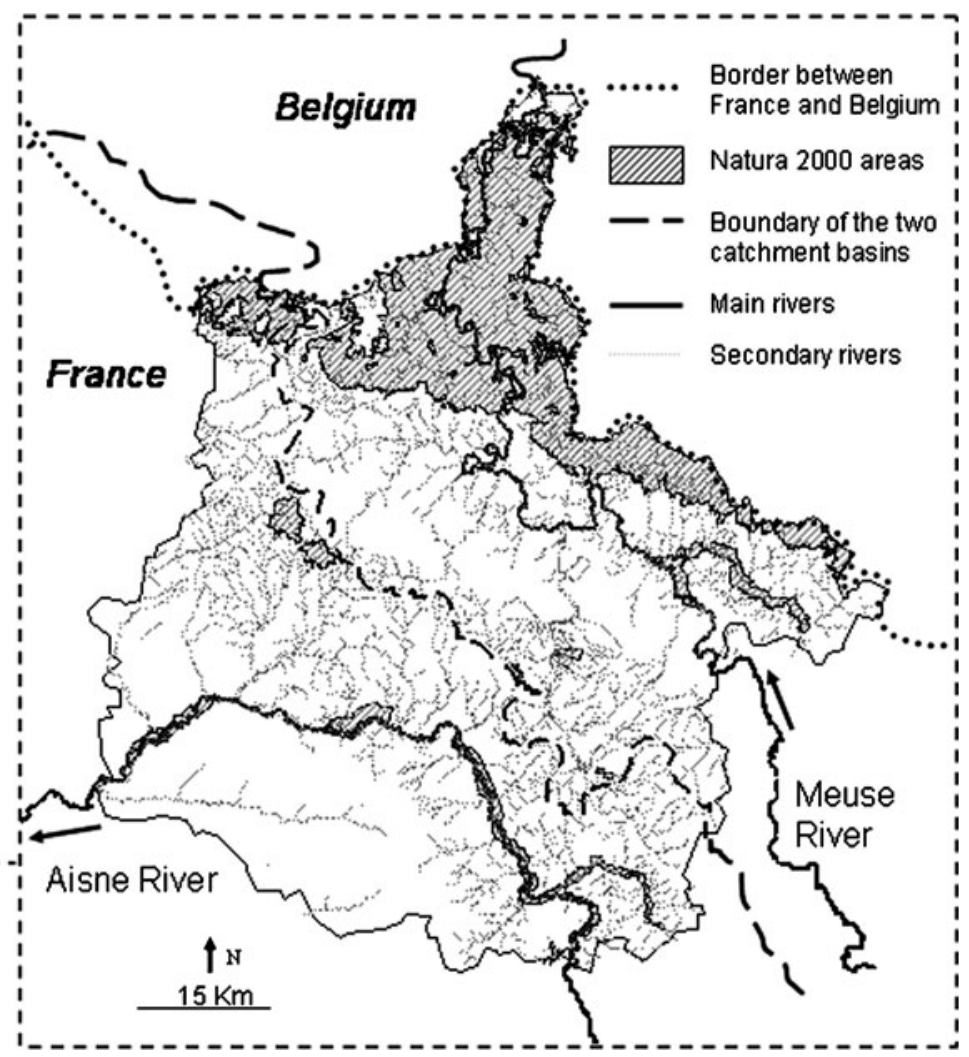

Fig. 1 Geographic location of the French Ardennes region (left). Hydrographic system and Natura 2000 areas (right)

The northern part, a schist massif (average elevation $300 \mathrm{~m}$ ) has a colder climate than the other parts and is covered by a dense coniferous forest. The hilly central part is devoted to breeding and farming of cows and sheep. The southern region, calcareous and warmer than the two previous regions, has crop farming.

The two parts of the hydrographic system are the northeastern one with the Meuse River and its tributaries belonging to the Meuse River basin and the southwestern one with the Aisne River and its tributaries belongs to the Seine River basin (Bazin 2004; Fig. 1).

\section{Methods}

Data sampling

A number of 29 waterways were sampled, each $500 \mathrm{~m}$ long and $20 \mathrm{~m}$ wide perpendicular from the water to the land (Fig. 2). This length corresponds, according to literature, to an optimal size of survey for muskrat, coypu and beaver territories along waterways (Robicheaux 1978 in Jouventin et al. 1996; Willner et al. 1980; Müller-Schwarze and Sun 2003). The minimum distance between two sites was $2 \mathrm{~km}$, although most sites are generally separated by at least $5 \mathrm{~km}$. Sampled sites were chosen to capture regionally variation in hydrography. Abiotic and vegetation data were measured once at each site, between April and August 2007, so fall and winter requirements were not studied here. Nine abiotic variables were measured (Willner et al. 1980; Erôme 1982; Allen 1983; Allen and Hoffman 1984; Woods et al. 1992; Corriale et al. 2006). Water depth, bank height, bank slope, ground texture (silty, organic or sandy) and ground structure (agregate or compact) were measured every $100 \mathrm{~m}$ (from 0 to $500 \mathrm{~m}$ ) on each bank, i.e. 12 measures for each sampling site. Waterway width (using a range finder) and water velocity were measured twice: at the beginning and at the end of each waterway section. Waterway gradient and altitude, the most upstream point, were measured precisely using the Geographic Information System (GIS, Arcview GIS 1996 Version 3.2). Plant taxa were studied by surveying areas of $500 \times 20 \mathrm{~m}$ on each bank. Plant identification was done in the field or in the laboratory when needed. So "taxa" is a species or, when the plant could not be identified to species, a genus. Abundance-dominance plants and their height were estimated visually and classified from 1 to 5 , respectively: $1<5 \%$; 2 $5-25 \% ; 325-50 \% ; 450-75 \% ; 575-100 \%$ and $10-40 \mathrm{~cm}$; $240-100 \mathrm{~cm} ; 3100-200 \mathrm{~cm} ; 4200-500 \mathrm{~cm} ; 5>500 \mathrm{~cm}$. Ten sites were sampled but excluded from the study because of their inaccessibility and doubt about the species' presence. Finally, 29 sampling sites were kept, of which 11 
Fig. 2 Sampling sites with presence-absence of the common muskrat, the coypu and the European beaver in the French Ardennes region

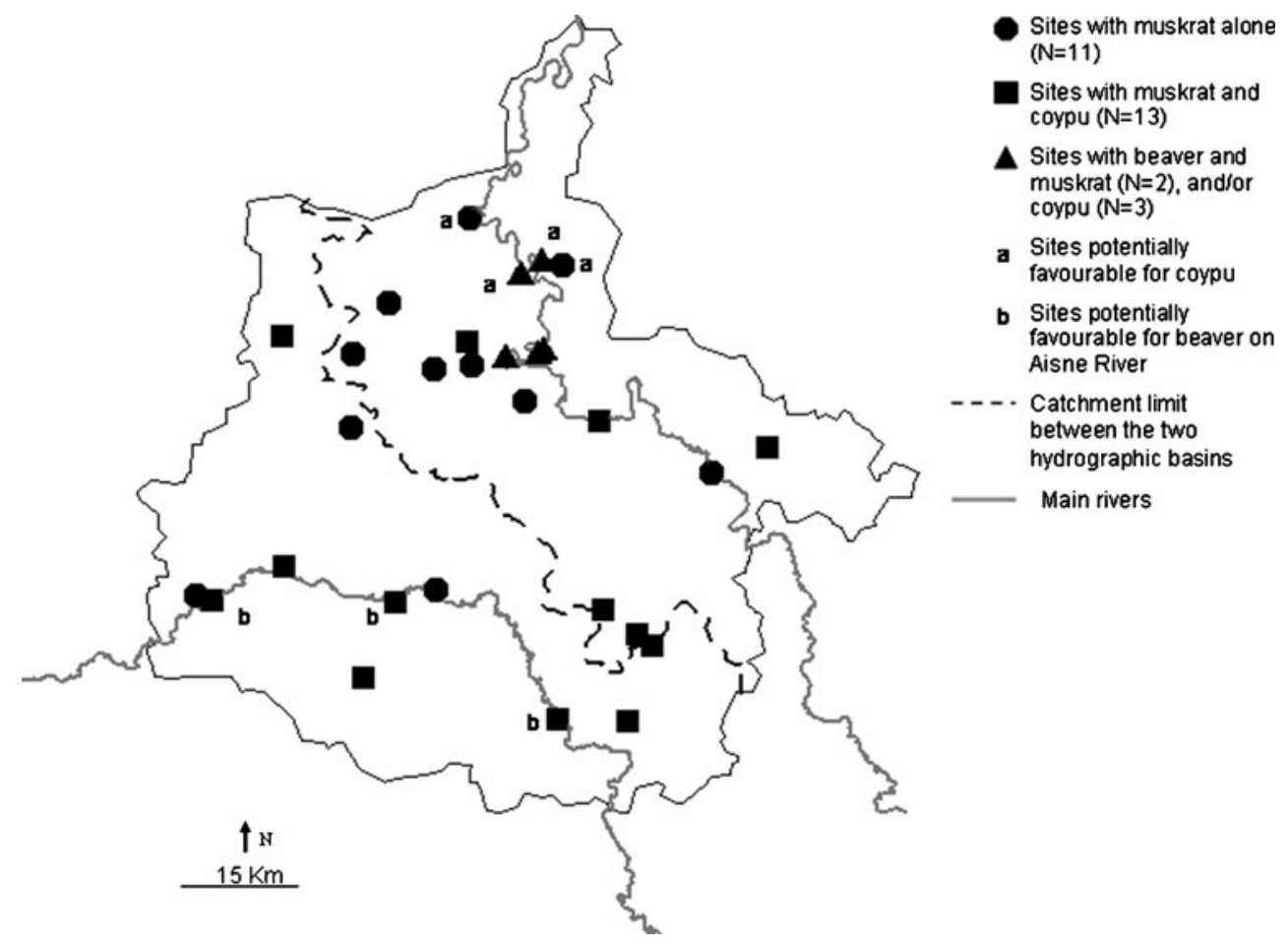

had the muskrat alone (muskrat sites), 13 had muskrats and coypus (muskrat-coypu sites), 2 had beavers and muskrats and 3 had beavers, muskrats and coypus. These two last groups were joined in beaver-muskrat-coypu sites $(N=5$; Fig. 2). The four northern sites, with beavers and muskrats, were considered as "potentially favourable for the coypu" even though they were outside its current distribution, because the species might potentially settle there following waterways ( $a$ sites in Fig. 2). In order to discuss beaver colonisation, we selected sites on the Aisne River where ecological conditions seemed similar to those of the Meuse River sites where the beaver is present. Amongst the 29 initial sites, we selected three sites on the Aisne River used by coypus and muskrats. These sites were considered as "potentially favourable sites for beavers" because the species could settle there by following waterways, even though they were outside its current distribution area $(b$ sites in Fig. 2). Every sampling site had at least one species. In cases where a single species was observed, it consisted of the muskrat. Sites without muskrats exist in the French Ardennes but there was not enough to compare to other sites with rodents. Consequently, the choice was made to consider muskrat sites as a baseline for comparisons with coypu and beaver sites. Sites were first selected using reports of the French game and wildlife national office [French Office National de la Chasse et de la Faune Sauvage (ONCFS)], wildlife managers, naturalists and hunters in the last 2 years. ONCFS rangers work in the whole French Ardennes region. The presence or absence of the species was then checked by a field research of rodent activity signs (prints, burrows, droppings or food marks). Beaver activity was associated with cut trees or branche, whereas scattered unionid shells were interpreted as a reliable indication of muskrat (Hanson et al. 1989; Leau and Léger 2006). Information was compiled using GIS. This method of investigation has advantages (large covered area and observations by experienced rangers, which implies reliable data) but also disadvantages (sampling not standardised and incomplete).

A number of 11 sampling sites belong to Natura 2000 areas and three were close to Natura 2000 areas $(<500 \mathrm{~m}$; Fig. 1). Of these sampling sites, two were beaver-muskratcoypu sites, five were muskrat-coypu sites and four were muskrat sites. Natura 2000 sites are integrated into an ecological European network to preserve biodiversity by maintaining or restoring habitats. Protected areas in the Ardennes include Special Protection Areas (SPA, strictly protected sites classified in accordance with Article 4 of the Directive 79/409/EEC of 2 April 1979 on the conservation of wild birds) and Special Areas of Conservation (SAC, strictly protected sites designated under the Directive 92/43/ EEC of 21 May 1992 on the conservation of natural habitats and of wild fauna and flora).

\section{Statistical analyses}

The relationship between mammals and habitat structure (such as abiotic and vegetation characteristics of waterways) was explored using canonical correspondence analysis (CCA) with the software CANOCO (Ter Braak 1987). 
CCA is a canonical ordination method developed to directly relate multivariate ecological data matrices. This method assumes that species have unimodal distribution along environmental gradients. It generates a diagram that displays approximate values of the weighted averages of species or sites with respect to the supplied explanatory variables, represented by arrows that point in the direction of factors with maximum variation (Ter Braak and Verdonschot 1995; Bernez et al. 2004). Arrows allow to directly visualise main ecological factors responsible for biological structures. From all explanatory variables, the best predictors were selected by a forward selection procedure, which is a multivariate extension of the stepwise regression method (Ter Braak 1990). For each CCA, a Monte Carlo simulation of both first axis eigenvalue and trace (i.e. the sum of all canonical eigenvalues) was used to test significance of analysed effects (Ter Braak 1990). The two matrices created were 'macrophyte taxa' $\times$ 'sampling sites' (response variable) and 'environmental variables' $x$ 'sampling sites' (explanatory variables).

Following the method of Fustec and Cormier (2003), abundance-dominance values were transformed into mean vegetation cover: (1) $2.5 \%$, (2) $12.5 \%$, (3) $37.5 \%$, (4) $62.5 \%$ and (5) $87.5 \%$. Height values were transformed into mean vegetation height: (1) $20 \mathrm{~cm}$, (2) $70 \mathrm{~cm}$, (3) $150 \mathrm{~cm}$, (4) $350 \mathrm{~cm}$ and (5) $500 \mathrm{~cm}$. A total of 186 riparian plant taxa were identified, from which 131 were used in the analysis because they were present in a minimum of 3 out of the 29 sites. We used nonparametric Mann-Whitney test (StatXact 1989-1997 Version 3.1), which is based on median equality and does not assume Gaussian distribution or equal standard deviations, to compare current beaver sites to other sites, current beaver sites to potential beaver sites, current muskrat-coypu sites to current muskrat sites and current muskrat-coypu sites to potential coypu sites.

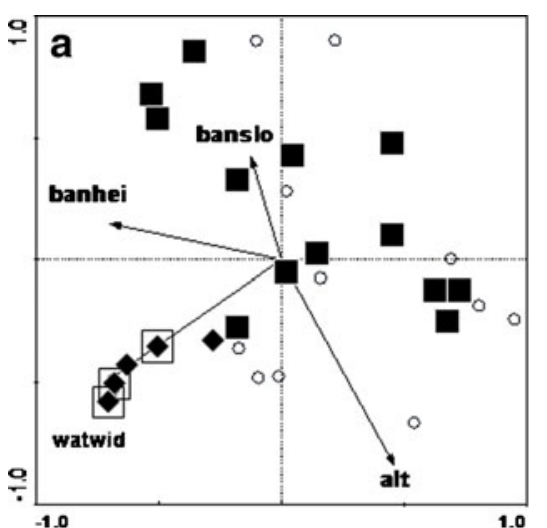

Fig. 3 Canonical correspondence analysis of actual sites with European beaver, coypu and muskrat in the French Ardennes region. Acronym given in Table 2. a Filled squares are muskrat-coypu sites $(N=13)$, filled diamonds are sites with beaver and muskrat $(N=2)$,

\section{Results}

The Ardennes waterways vary from wide deep rivers or alluvial valleys to narrow waterways pinned between cultivations and meadows. The riparian area of our survey is characterised by a patchy structure, with a common biodiversity dominated by ruderal and/or ubiquitous species: trees and shrubs (Alnus glutinosa, Salix spp., Fraxinus excelsior and Prunus spinosa) and herbaceous plants (Urtica dioica, Poaceae spp., Filipendula ulmaria, Ranunculus repens and Callitriche obtusangula).

The eigenvalues of the first two canonical axes explained $13.3 \%$ to $17.5 \%$ of the total floristic variability and $34.5 \%$ to $60.8 \%$ of the species-environment relationships, which correspond to typical levels in hydrobiological studies (Bernez et al. 2004). The manual forward selection procedure of the CCA retained four environmental variables: altitude, waterway width, bank height and bank slope (Fig. 3; Table 2). Discriminative plant taxa were: Betula spp., Pinaceae, Ribes rubrum, Circaea lutetiana, Cynosurus cristatus, Dipsacus pilosus, Fallopia japonica, Juncus effusus, Lycopus europaeus, Origanum vulgare, and Zea mays. Common plants were Salix spp., A. glutinosa, Crataegus spp., F. excelsior, Poaceae, Hedera helix, Rubus fructicosus, Cirsium arvensis, Carex panicula, Calystegia sepium, Iris spp., Hypericum spp., Taraxacum spp. Lythrum salicaria and Equisetum fluviatile. Height and abundancedominance plants were not correlated with rodent's presence-absence from any angle.

\section{Beaver}

The multidimensional analysis pointed out a homogeneous group of four river sites that are beaver-muskrat-coypu sites (Fig. 3a). The sites were wider (59 vs. $17 \mathrm{~m}, p<0.01$ )

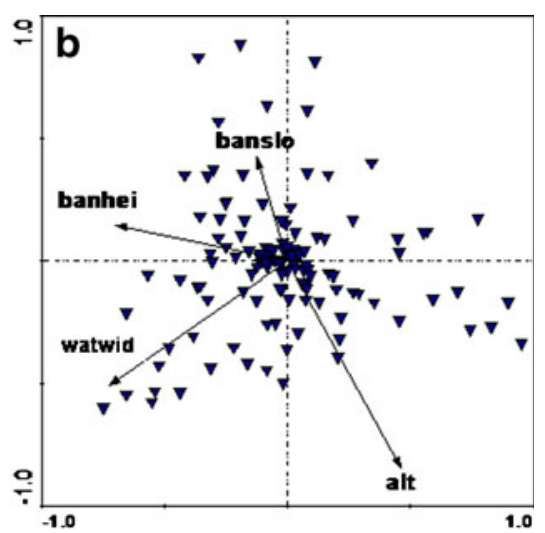

filled diamonds and empty squares are sites with beaver, muskrat and coypu $(N=3)$, hollow circles are sites with common muskrat alone $(N=11) . b$ Triangles are plant taxa 
Table 2 Abiotic variables forward selected and their correlation with the first two canonical axes from the canonical correspondence analysis of aquatic plant taxa of French Ardennes waterways

\begin{tabular}{|c|c|c|c|c|c|}
\hline \multirow[t]{2}{*}{ Abiotic variables } & \multirow[t]{2}{*}{ Unit } & \multicolumn{2}{|c|}{ Forward selection } & \multicolumn{2}{|c|}{ Correlation with canonical axes } \\
\hline & & $F$ ratio & $p$ Value & Axis 1 & Axis 2 \\
\hline Altitude (alt) & M & 1.77 & 0.002 & 0.434 & -0.785 \\
\hline Waterway width (watwid) & M & 1.81 & 0.002 & -0.685 & -0.471 \\
\hline Bank height (banhei) & M & 1.46 & 0.012 & -0.659 & 0.137 \\
\hline Bank slope (banslo) & $\circ$ & 1.45 & 0.014 & -0.118 & 0.393 \\
\hline
\end{tabular}

but were not distinct from other sites in terms of their bank height (183 vs. $126 \mathrm{~cm}$ ) or number of plant taxa (53 vs. 45; Table 4). Eighteen woody genera were found in beavermuskrat-coypu sites (Table 3). In beaver-muskrat-coypu sites, Betula spp. and Carpinus spp. are significantly more present and are more abundant $(p<0.001$ and $p<0.05$, respectively) but $F$. excelsior is only more abundant $(p<$ $0.05)$ than in other sites without beaver. Finally, species of Pinaceae are more present $(p<0.05)$ in beaver-muskratcoypu sites than in sites without beaver. In beaver-muskratcoypu sites, 11 plant taxa are predominant in the CCA analysis (Fig. 3b): Betula spp., Malus spp., Carpinus spp., Pinaceae, and herbaceous: F. japonica (invasive species), Polypodium spp., Tanacetum vulgare, O. vulgare, Epilobium

Table 3 Tests of presence-absence and abundance-dominance for 12 woody species between sites with beaver and sites without beaver in the French Ardennes region

\begin{tabular}{|c|c|c|c|c|}
\hline \multirow{2}{*}{$\begin{array}{l}\text { Woody } \\
\text { genera }\end{array}$} & \multicolumn{2}{|c|}{ Presence-absence } & \multicolumn{2}{|c|}{$\begin{array}{l}\text { Abundance- } \\
\text { dominance }\end{array}$} \\
\hline & $\begin{array}{l}\text { Percent sites } \\
\text { with beaver } \\
(N=5)\end{array}$ & $\begin{array}{l}\text { Percent sites } \\
\text { without beaver } \\
(N=24)\end{array}$ & & \\
\hline Acer spp. & 100 & 71 & NS & NS \\
\hline Alnus glutinosa & 100 & 96 & NS & NS \\
\hline Betula spp. & 80 & 0 & $* * *$ & $* * *$ \\
\hline Carpinus spp. & 60 & 13 & $*$ & * \\
\hline Corylus spp. & 60 & 46 & NS & NS \\
\hline Crataegus spp. & 100 & 96 & NS & NS \\
\hline Fagus sylvatica & 60 & 21 & NS & NS \\
\hline Fraxinus excelsior & 100 & 83 & NS & $*$ \\
\hline Malus spp. & 40 & 13 & NS & NS \\
\hline Pinaceae spp. & 60 & 8 & $*$ & NS \\
\hline Platanus spp. & 20 & 13 & NS & NS \\
\hline Populus spp. & 60 & 63 & NS & NS \\
\hline Prunus spinosa & 60 & 79 & NS & NS \\
\hline Quercus spp. & 60 & 50 & NS & NS \\
\hline Salix spp. & 100 & 96 & NS & NS \\
\hline Sorbus spp. & 0 & 21 & NS & NS \\
\hline Tilia platyphyllos & 20 & 4 & NS & NS \\
\hline Viburnum opulus & 0 & 29 & NS & NS \\
\hline
\end{tabular}

NS Not significant

${ }^{*} p<0.05 ; * * * p<0.001$ angustifolium, Lathyrus pratensis and Achillea millefolium. The four last species are found in a majority of beavermuskrat-coypu sites. There is no difference in the values of abundance-dominance plants between beaver-muskratcoypu sites and other sites without beaver (Table 4).

\section{Coypu and muskrat}

As the muskrat was present in every sampled site, it was removed from the CCA analysis. Muskrat-coypu sites are widespread and no abiotic variable stands out (Fig. 3a). Coypu is indifferent to waterway width variations $(3-71 \mathrm{~m})$ and bank height variations (18-200 cm; Table 4). Common plant taxa did not change in muskrat and muskrat-coypu sites even if beaver-muskrat-coypu sites $(N=5)$ and woody species $(N=18)$ are excluded from the CCA analysis. These plants are Angelica sylvestris, C. sepium, Glechoma hederacea, $R$. fructicosus, Cirsium vulgare, H. helix, Taraxacum spp., Crepis spp., Dactylis glomerata, other Poaceae, Rumex crispus, and E. fluviatile. Tests with abiotic and vegetation variables did not show a significant difference between muskrat-coypu and muskrat sites (Table 4) and no plant taxa are predominant in the CCA analysis.

Potential for beaver to colonise the South of the Ardennes

The second widest waterway, apart from the Meuse River where beavers are already present, is the Aisne River in the South of the Ardennes (Fig. 2). Compared to beavermuskrat-coypu sites, potential beaver sites have narrower waterways (35 vs. $59 \mathrm{~m}, p<0.05$ ) and steeper bank slopes ( $66^{\circ}$ vs. $\left.47^{\circ}, p<0.05\right)$. However, bank height is similar (164 vs. $183 \mathrm{~cm}$; Fig. 4a). The number of herbaceous and woody species did not differ between potential beaver sites and beaver-muskrat-coypu sites. Amongst the 18 woody genera taken into account, Betula is absent and Carpinus is found in one out of the three sites. Fraxinus is the only genus present in the three sites even if its abundance is not significant (Table 3). CCA analysis shows four predominant plant taxa in sites potentially favourable for beaver: Sorbus spp., Arctium, Artemisia vulgaris and Z. mays (Fig. 4b). There was no difference in the number of plant taxa, mean vegetation cover and height between beaver sites and potentially favourable beaver sites (Table 4). 
Table 4 Comparison of means of habitat variables for sites located in the North of the French Ardennes region

Sites with the current or potential presence of beaver

\begin{tabular}{|c|c|c|c|}
\hline$a$ & $B$ & $c$ & $p$ Value \\
\hline $\begin{array}{l}\text { Sites with } \\
\text { beaver } \\
(N=5)\end{array}$ & $\begin{array}{l}\text { Sites without } \\
\text { beaver } \\
(N=24)\end{array}$ & $\begin{array}{l}\text { Potential } \\
\text { beaver sites } \\
(N=3)\end{array}$ & $(a-b)$ \\
\hline
\end{tabular}

Sites without the presence of beaver, only muskrat and/or coypu

\begin{tabular}{lllll}
\hline & $e$ & $f$ & \multicolumn{2}{l}{$p$ Value } \\
\cline { 5 - 6 } $\begin{array}{l}\text { Muskrat- } \\
\begin{array}{l}\text { coypu sites } \\
(N=13)\end{array}\end{array}$ & $\begin{array}{l}\text { Muskrat } \\
\text { sites } \\
(N=11)\end{array}$ & $\begin{array}{l}\text { Potential } \\
\text { coypu sites } \\
(N=4)\end{array}$ & $(d-e)$ & $(d-f)$ \\
43 & 48 & 55 & NS & $* *$ \\
8 & 8 & 11 & NS & NS \\
36 & 40 & 44 & NS & NS
\end{tabular}

45
8
39

$\begin{array}{rll}46 & \text { NS } & \text { NS } \\ 8 & \text { NS } & \text { NS } \\ 39 & \text { NS } & \text { NS }\end{array}$

\section{1}

10

Herbaceous taxa

10

\section{1}

12 NS NS

Mean vegetation height $(\mathrm{cm})$
Woody taxa $\quad 382$

Herbaceous taxa

72

337

70

CCA abiotic characteristics

Waterway width $(\mathrm{m})$

Bank height $(\mathrm{cm})$

Bank slope $\left({ }^{\circ}\right)$

$\begin{array}{rr}59 & 17 \\ 183 & 126 \\ 47 & 50\end{array}$

$\begin{array}{rll}365 & \text { NS } & \text { NS } \\ 70 & \text { NS } & \text { NS } \\ & & \\ 35 & * & * * \\ 164 & \text { NS } & \text { NS } \\ 66 & \text { NS } & * *\end{array}$

12

10

350

71

15

138

49

10

9

$\begin{array}{lll}10 & \text { NS } & \text { NS } \\ 10 & \text { NS } & \text { NS }\end{array}$

Values are means. $p$ Value is the result of Mann-Whitney test. A taxa is a species or a genera when species was not identified $C C A$ Canonical correspondence analysis, NS not significant

${ }^{*} p<0.01 ; * * p<0.05$

Potential for coypu to colonise the North of the Ardennes

The four sites potentially favourable for coypu are situated in the North of the Ardennes (Fig. 2). Amongst these four sites, two have beaver and muskrat and the two others have only muskrat. Sites potentially favourable for coypu are wider (57 vs. $15 \mathrm{~m}, p<0.01$ ), have more plant taxa (55 vs. $43, p<0.05$ ) and herbaceous species are higher (94 vs. $71 \mathrm{~cm}, p<0.05$ ) than muskrat-coypu sites (Table 4). In potentially favourable coypu sites, herbaceous plant taxa related to the CCA analysis are $F$. japonica, O. vulgare, E. angustifolium, L. pratensis, A. millefolium and Polypodium spp. (Fig. 4b).

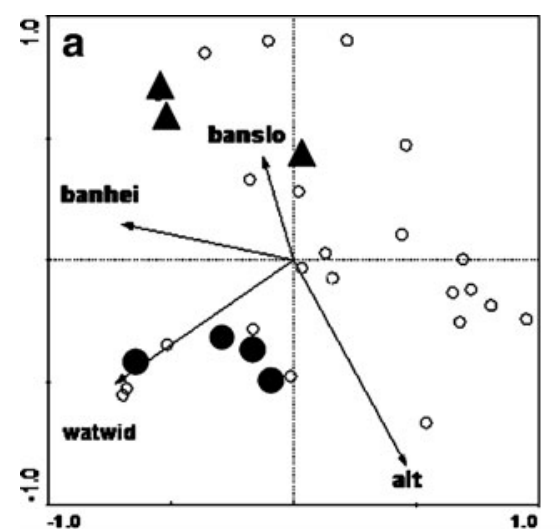

Fig. 4 Canonical correspondence analysis of sites potentially favourable for European beaver and coypu in the French Ardennes region. Acronym given in Table 2. a Filled triangles are sites potentially favourable for European beaver in the Aisne River $(N=3)$, filled

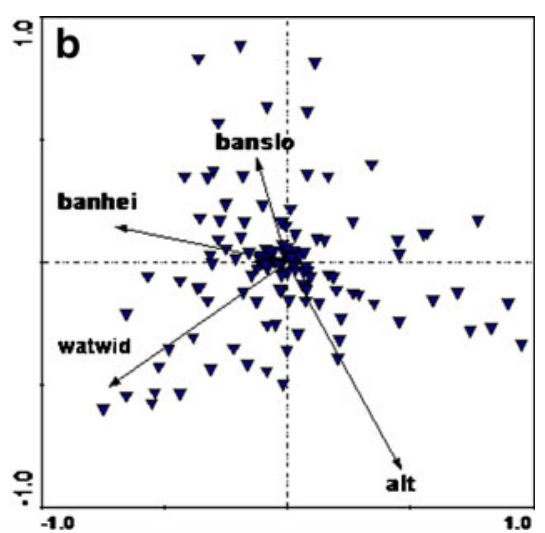

circles are sites potentially favourable for coypu downstream the Meuse River $(N=4)$ and hollow circles are all other sites in the study $(N=22)$. $b$ Triangles are plant taxa 


\section{Discussion}

\section{The current situation}

In most cases, beavers seem to select the widest available waterways, such as the Meuse River, which have banks high enough for burrowing, even though their cavities or huts could be used (Erôme 1982). Wide waterways present two advantages for beavers: the water level is relatively constant compared to narrow waterways so that flood events and risk of damage to burrows is decreased; and water depth is greater than $50 \mathrm{~cm}$, which is the minimum level required for beaver settlement (Müller-Schwarze and Sun 2003; Rosell et al. 2005). However, variations in the annual water regime were not estimated here but could have consequences on beavers' food cache (Nolet and Rosell 1998). Collen and Gibson (2001) showed that during the process of colonisation, beavers first choose the 'good' habitat. Beavers are currently colonising the French Ardennes, and the presence of five families in 2006 in the Meuse River indicates that this river probably constitutes preferred habitat (Leau and Léger 2006); the population is therefore expected to increase. By contrast, muskrats and coypus are less selective than beavers for habitat. Muskrats seem indifferent to the abiotic conditions of the waterway. The species is indeed found in wide and narrow waterways with high or low banks. The muskrat's ecological limits, such as fast-flowing streams, variations in water level, high water gradient, rocky banks, sandy soil, are localised in the northern part of the French Ardennes (Allen 1983; Nadeau et al. 1995). The coypu can be found in waterways with low banks and use nests instead of burrows (Jouventin et al. 1996). Our results confirmed the behavioural adaptability of muskrats and coypus, and their capacity to live in a variety of environments (Danell 1977; Messier et al. 1990; Jouventin et al. 1996; Corriale et al. 2006). However, in the Ardennes region, the coypu is absent from several waterway sections within its distribution range despite seemingly suitable environmental conditions. This result could be explained by a low coypu density due to the local trapping rate or other variables not measured or not detected on a local scale.

More than 140 herbaceous species are known to occur in the beaver's diet (review in Erôme 1982), and most of the 186 plant taxa identified in this study are potentially consumed by beavers. E. angustifolium, L. pratensis and A. millefolium, particularly found in beaver sites, are likely consumed along with other herbaceous species in late spring and summer (directly observed on beaver sites) and could provide an important nutrient complement (Nolet et al. 1994; Ganzhorn and Hartum 2000). But the staple diet consists of woody species consumed in the fall and winter (Rosell et al. 2005). In the Ardennes, Salix spp. and $A$. glutinosa are widely present, Populus spp. is less represented and Fraxinus excelsior is abundant in every beaver site. Our observations on the presence of these four woody species are similar to those of Nolet et al. (1994), Ganzhorn and Hartum (2000) and Collen and Gibson (2001), who found them to be positively associated with sites selected by beavers. In their review, Collen and Gibson (2001) wrote that Alnus spp. is used principally for construction, and Betula spp. is less used than Salix spp. However, in the Ardennes, Betula spp. is always found in beaver sites, and Carpinus spp. seem to play a major role in beaver settlement. Pinaceae are also overrepresented in beaver sites, but this taxa is only occasionally consumed by beavers (Collen and Gibson 2001). We cannot conclude that these woody species are positively selected by beavers because we did not study foraging behaviour. However, the relation between beaver settlement and the presence of these plant species is interesting. Other plants are less (or not) consumed by beaver (Rosell et al. 2005). In the muskrat and muskrat-coypu sites, there are no significant differences in abiotic and floristic characteristics and the two species can be found in the same environments, as already shown by Swank and Petrides (1954), Gosling and Baker (1989) and Baroch and Hafner (2002). Plants, such as Poaceae, R. crispus and E. fluviatile, are found in both types of sites. According to the literature, muskrat and coypu diets are similar; the two species consume a large variety of plants where monocotyledons are predominant (Danell 1979; Willner et al. 1980; Abbas 1988; Borgnia et al. 2000; Guichón et al. 2003). There could therefore be a niche overlap for food between these two rodents in sites where they are both present. This phenomenon may be stronger in periods of food shortage such as winter, even if resources were not evaluated in this study. Muskrats and coypus can have a large impact on vegetation and abiotic environments when they occur at high densities (Connors et al. 2000; Higgins and Mitsch 2001; Curtet et al. 2008). Protected or sensitive areas, e.g. Natura 2000 areas, must receive particular attention, and specific management plans must be implemented so as not to harm protected or native species (Prigioni et al. 2005; Panzacchi et al. 2007).

Predation pressure is low in the Ardennes and does therefore not seem to limit beaver, coypu and muskrat settlement. For American and European beavers, the main predator is the wolf (Canis lupus; Halley and Rosell 2002; Müller-Schwarze and Sun 2003), but this carnivore is absent from the Ardennes, as are brown bears (Ursus arctos) and lynxes (Lynx lynx). Adult beavers therefore experience no predation pressure. Young beavers can be predated by badgers (Meles meles) and otters (L. lutra; Véron 1991), but in the first case, it is rare and there are no otters in the Ardennes. As in South America for the American beaver, the Ardennes are optimal for a beaver 
invasion, thanks to the low predation pressure and suitable resources (Anderson et al. 2009). In the same way, adult coypus do not have any predators in Europe, which is not the case in their native range (Jouventin et al. 1996). There are cases of predation by dogs or otters but they are rare in France (Le Louarn and Quéré 2003). Finally, muskrats can be preyed upon by red foxes (Vulpes vulpes), polecats (Mustela putorius), otters and birds of prey. However, predation pressure does not seem to have any effect on the muskrat population dynamic (Le Louarn and Quéré 2003).

Following escapes and releases from fur farms, muskrats are widely spread in the French Ardennes region and throughout Belgium (Libois 2006). Coypus arrived in the Ardennes in the 1990s and quickly colonised the region; only the northern part has not yet been affected (Léger 2007). Moreover, in Belgium, coypus are not very frequent because of intensive trapping (Verbeylen 2002). On the other hand, beavers were mainly reintroduced along the French-Belgian border, so the population regularly increases in the Ardennes and Belgium (Leau and Léger 2006; Libois 2006). However, the colonisation of the Ardennes by beavers is recent and the species is therefore present on a low number of sites. Five families were installed on the Meuse River in 2006 (Leau and Léger 2006). The difficulty was to find all the sites where the beaver was present. Moreover, some beavers were in marshes or closed waters (excluded of the study) and the accessibility of sampled sites was an essential factor. These elements will be taken into account in the interpretation of results and the conclusion.

Potential situations of colonisation and management

In the Ardennes, waterway width seems to be a major abiotic factor for beaver settlement. On the Aisne River, the second widest river of the Ardennes, bank slope could play a role in vegetation characteristics and is therefore an indirect abiotic factor for beaver settlement (Erôme 1982). According to variables on present sites, potentially favourable sites for beavers exist in the Ardennes. Three plants, $A$. vulgaris, Sorbus spp. and Z. mays, can complete spring and summer diets (Erôme 1982). However, Betula spp. and Carpinus spp. are not abundant. Consequently, if beavers colonise one of these sites, other woody species, i.e. Salix spp., Fraxinus spp. or Alnus spp., will have to make up the bulk of the winter staple diet (Collen and Gibson 2001).

In potentially favourable coypu sites, the number of plants and their height are greater than in present coypu sites but may not constitute a limiting factor for coypu spread (Jouventin et al. 1996). Severe winters and several consecutive days of subzero temperatures, which occur frequently in the northern part of the Ardennes, are limiting factors for the coypu (Doncaster and Micol 1990; Carter and Leonard 2002). However, the presence of the species in similar conditions in Belgium reveals that coypus could nevertheless rapidly colonise the area. It is possible to eradicate coypus or muskrats but only in a few restrictive situations: in insular situation as in Great Britain in the 1980 s, or when the populations are small and isolated, as in Lake Trasimeno in Italy (Gosling and Baker 1989; Velatta and Ragni 1991 in Panzacchi et al. 2007). By contrast, an eradication campaign was carried out in an area with a high immigration rate and had no effect (Cocchi and Riga 2001 in Panzacchi et al. 2007). One of the solutions is to maintain low densities, preferentially by trapping, to avoid widescale damage (Carter and Leonard 2002).

Our results about potential favourable sites for the European beaver and the coypu can be discussed. First, all favourable sites could not be identified because favourable modalities for establishment of beaver and coypu are not completely known. Second, we cannot prove that the two species will colonise the sites that we identified, even if biotic and abiotic factors are promising. Third, time of spread is difficult to estimate. For example, the current situation of beaver has allowed us to calculate a dispersal rate of $4.7 \pm 2.6 \mathrm{~km} /$ year. This result was calculated on Meuse River between 1999 and 2007. However, according to other data, the European beaver is able to travel long distances in search of suitable territory: 37.6 km/year on Loire River in France (Fustec et al. 2001). The invasion process of beaver is at its beginning in the French Ardennes and the answer to the question of when beaver will arrive in potentially favourable sites is difficult. Furthermore, only one part of potential favourable sites can be taken into account, those which correspond to sites that are accessible and with the same features as current known sites. Other sites with other features are probably potentially favourable but current knowledge cannot allow us to identify them. The beaver invasion comes from North, where favourable sites are occupied, and runs to South, where potentially favourable sites are present, and conversely for coypu. Only a population survey could tell us if beaver and coypu will choose potentially favourable sites selected in this study.

For the beaver and coypu, we suggest developing ecological monitoring (Carillo et al. 2000; Bisbal 2001). The management objective could be twofold: first, preserve the beaver population by identifying suitable sites for its settlement and barriers of spread; second, detect coypu arrival downstream, its present North limit on the Meuse River and limit its spread. For the beaver, the first step is to evaluate available riparian woods on the Aisne River. Modern tools, such as aerial pictures and GIS coupled with available land cover, give precise information, thus avoiding complete landscape assessment and reducing costs (Macdonald et al. 2000; Maringer and Slotta-Bachmayr 
2006). The second step is to select the potentially most suitable sites considering abiotic parameters (slope, width, water depth, etc.) by field assessments and estimate the quantity and quality of woody species. Finally, the last step is to develop field surveys by regular observations on selected sites to detect the beaver's arrival and give recommendations to protect the species and its environment (Rosell et al. 2006). If riparian woody species prove insufficient, ecological riparian restoration, by Salix spp. Plantations, for example, could be considered (Nolet and Rosell 1998; Pieret et al. 2008). For coypus and muskrats, regular dusk and/or dawn observations should be done, associated with the detection of presence marks (Engeman and Whisson 2003). If the coypu's presence is detected, trapping sessions should be carried out to remove the first individuals and quickly stop them spreading. Cage-traps will avoid the destruction of protected species, such as beavers, and could be used for muskrats too (Jouventin et al. 1996).

Potentially favourable sites for beaver and coypu settlement often have woodlands with particular alluvial species, such as elm (Ulmus spp.), and are therefore included in Natura 2000 areas. Most of the aquatic Natura 2000 areas in the Ardennes have management programs based on the preservation of wetlands and streams, particularly to avoid bank and stream damage and to conserve associated species (plants, insects and fish). What could the consequences be if rodents settled in such sites? In high densities, coypus can reduce emergent plants, forming areas of open waters and interrupting the process of plant succession in freshwater marshes (Woods et al. 1992; Jouventin et al. 1996). Furthermore, the grasing of muskrats can disturb riparian habitat structure and increase the predation of invertebrates by fish (Nummi et al. 2006). Altogether, alien rodents could have strong negative effects on riparian biodiversity, especially in Natura 2000 areas. The beaver's activities modify the ecosystem but the species would function as a natural manager of the riparian environment, especially on woody species: cutting riparian trees allows the recurrence of plants, a better root development which consolidates banks, better shoots consumed by other species, such as ungulates, and provides habitats for birds (Rosell et al. 2005). Beavers could be an additional argument for Natura 2000 protected areas as they are a key component in the restoration of the functioning of the riparian ecosystem. Although French law protects the European beaver, we should remain cautious. In French Ardennes, beaver have lost his native enemies, and its current impact on ecosystem could transform it into a pest as it is the case with the European wild rabbit (Oryctolagus cuniculus) in its native range (Lees and Bell 2008).

More generally, an area where beavers may settle could become a protected area because of the species' status.
Therefore, on a landscape scale, the spread of the species by aquatic corridors could create a real network of protected areas linked by water and allow global thinking about river management and conservation. We suggest considering beavers as a basic tool to develop ecosystem protection and conservation.

\section{Conclusion}

In the French Ardennes region, the presence of the common muskrat and coypu, two introduced species, and the reintroduction of the European beaver have changed the global viewpoint of scientists, managers and conservationists. This study is a first step towards better understanding of the interactions between these three species of aquatic rodents. We tried to explain the paradoxal situation of these three species, proposed a scenario for the future and suggested management strategy. However, other scenarios are possible, especially if colonisation of one or other of these three species is stopped in the coming years by lack of suitable sites. The results of this study were limited by the number of sample sites. Future research should include greater number of sampling sites. If possible, density or relative abundance of rodent species should also be measured. This study was undertaken in spring and summer 2007. It would be interesting to study rodent interactions in winter when resources are scarce. Collective efforts are necessary to develop ecological management tools for biodiversity conservation and the fight against introduced species. These actions must incorporate managers, conservationists and local communities on a large spatial scale to respond to the widespread invasion process. Ecological studies are also essential in protected areas in order to find out the real impact of rodents on ecosystem functioning and to understand interspecific interactions between muskrat, coypu and beaver. It would be particularly valuable to investigate how muskrat and coypu can interfere with habitat requirements of beaver. Food competition in summer and or perhaps the digging behaviour of coypu could affect physical habitat of beaver. Unfortunately, there is a lack of studies on aquatic rodent interactions, especially between beaver and coypu. The hypothesis that beaver could be used as a natural tool in maintaining low density in coypu populations should be tested, using a niche overlap effect, following an integrated management plan. Physical conditions of female coypu could be spoiled by the presence of high density of beavers. Similar research findings were found by Eccard and Ylonen (2002) on other rodents. Indeed, anecdotal observations in France showed that coypus avoid beavers when they swim in the opposite direction (ONCFS, personal communication). Beaver scent marking (castoreum) on coypu presence, first in captivity 
and then in situ, could be tested using the methods of Rosell et al. (1998) and Rosell and Bjørkøyli (2002). Finally, capture-mark-recapture could be used to evaluate relative abundances of beavers and coypus in different regions of France.

Acknowledgements The authors thank Marilyne Kneveler for her useful observations on riparian vegetation and Frances Bucquet, Ariane Dupéron, Aude Loisier and Martin Schlaepfer for their last reading. This study received financial supports from the Conseil Général des Ardennes and the Conseil Régional de Champagne-Ardenne.

\section{References}

Abbas A (1988) Impact du ragondin (Myocastor coypus Molina) sur une culture de maïs (Zea mays L.) dans le marais Poitevin. Acta Oecol, Oecol Appl 9:173-189

Allen AW (1983) Habitat suitability index models: beaver. U.S. Fish and Wildlife Service FWS/OBS-W10.30 Revised

Allen AW, Hoffman RD (1984) Habitat suitability index models: muskrats. U.S. Fish and Wildlife Service FWS/OBS-82/10.46

Anderson CB, Griffith CR, Rosemond AD, Rozzi R, Dollenz O (2006) The effects of invasive North American beavers on riparian plant communities in Cape Horn, Chile: do exotic beavers engineer differently in sub-Antartic ecosystems? Biol Conserv 128:467-474

Anderson CB, Pastur GM, Lencinas MV, Wallem PK, Moorman MC, Rosemond AD (2009) Do introduced North American beavers Castor canadensis engineer differently in Southern America? An overview with implications for restoration. Mamm Rev 39:33-52

Arcview GIS (1996) Version 3.2. Environmental Systems Research Institute, Inc. Redlands, USA

Baguette T (1994) Le castor, synthèse. Cah Ethol 14:357-380

Baldwin AH, Pendleton FN (2003) Interactive effects of animal disturbance and elevation on vegetation of a tidal marsh. Estuaries 26:905-915

Baroch J, Hafner M (2002) Biology and natural history of the nutria, with special reference to nutria in Louisiana. In: Baroch J, Hafner M, Brown TL, Mach JJ, Poché RM (eds) Nutria (Myocastor coypus) in Louisiana. A report prepared for the Louisiana Department of Wildlife and Fisheries by Genesis Laboratories. pp 3-22

Bazin M (2004) Les Ardennes. Une géographie pour notre temps. Eds Terres Ardennaises

Bernez I, Daniel H, Haury J, Ferreira M-T (2004) Combined effects of environmental factors and regulation on macrophyte vegetation along three rivers of western France. River Res Appl 20:43-59

Bisbal GA (2001) Conceptual design of monitoring and evaluation plans for fish and wildlife in the Columbia River ecosystem. Environ Manage 28:433-453

Blanchet M (1977) Le Castor et son royaume. Ligue Suisse pour la Protection de la Nature, Neuchâtel, Switzerland

Borgnia M, Galante ML, Cassini MH (2000) Diet of the coypu (Nutria, Myocastor coypus) in agro-systems of Argentinean pampas. J Wildl Manage 64:354-361

Breck SW, Wilson KR, Andersen DC (2003) Beaver herbivory and its effect on cottonwood trees: influence of flooding along matched regulated and unregulated rivers. River Res Appl 19:43-58
Carillo E, Wong G, Cuaron AD (2000) Monitoring mammal populations in Costa Rican protected areas under different hunting restrictions. Conserv Biol 14:1580-1591

Carter J, Leonard BP (2002) A review of the literature on the worldwide distribution, spread of, and efforts to eradicate the coypu (Myocastor coypu). Wildl Soc Bull 30:162-175

Clark WR (1994) Habitat selection by muskrats in experimental marshes undergoing succession. Can J Zool 72:675-680

Colautti RI, MacIsaac HJ (2004) A neutral terminology to define "invasive" species. Divers Distrib 10:135-141

Collen P, Gibson RJ (2001) The general ecology of beavers (Castor spp.), as related to their influence on stream ecosystem and riparian habitats, and the subsequent effects on fish-a review. Rev Fish Biol Fish 10:439-461

Connors LM, Kiviat E, Groffman PM, Ostfeld RS (2000) Muskrat (Ondatra zibethicus) disturbance to vegetation and potential net nitrogen mineralisation and nitrification rates in a freshwater tidal marsh. Am Midl Nat 143:53-63

Corriale MJ, Arias SM, Bo RF, Porini G (2006) Habitat-use patterns of the coypus Myocastor coypus in an urban wetland of its original distribution. Acta Theriol 51:295-302

Curtet L, Benmergui M, Broyer J (2008) Le dispositif exclos/témoin, un outil pour évaluer l'efficacité de la régulation du ragondin. ONCFS - Faune Sauvage 280:16-23

Danell K (1977) Dispersal and distribution of the muskrat (Ondatra zibethicus L.) in Sweden. Viltrevy Swed Wildl 10:1-26

Danell K (1979) Reduction of aquatic vegetation following the colonization of a northern Swedish lake by the muskrat, Ondatra zibethicus. Oecologia 38:101-106

Danilov PI (1992) Introduction of North-American semiaquatic mammals in karelia and its consequences for aboriginal species. Semiaquatische Säugetiere. Wiss Beit Univ Halle:267-276

Davis RA, Jenson AG (1960) A note on the distribution of the coypu (Myocastor coypus) in Great Britain. J Anim Ecol 29:397

De Nooij RJW, Lenders HJR, Leuven RSE, De Blust G, Geilen N, Goldschmidt B, Muller S, Poudevigne I, Nienhuis PH (2004) BIO-SAFE: assessing the impact of physical reconstruction on protected and endangered species. River Res Appl 20:299-313

Doncaster CP, Micol T (1990) Response by coypus to catastrophic events of cold and flooding. Holarct Ecol 13:98-104

Eccard JA, Ylonen H (2002) Direct interference or indirect exploitation? An experimental study of fitness costs of interspecific competition in voles. Oikos 99:580-590

Engeman RM, Whisson DA (2003) A visual method for indexing muskrat populations. Int Biodeterior Biodegrad 52:101-106

Erôme G (1982) Contribution à la connaissance éco-éthologique du castor (Castor fiber) dans la vallée du Rhône. Thèse de doctorat, Université Claude-Bernard, Lyon 1, France

Errington PL (1963) Muskrat populations. Iowa State University Press, Ames, IA

Fustec J, Cormier J-P (2003) The habitat potential of the downstream Loire River for European beavers (C. fiber). Lutra 46:109-116

Fustec J, Lode T, Le Jacques D, Cormier J-P (2001) Colonization, riparian habitat selection and home range size in a reintroduced population of European beavers in the Loire. Freshw Biol 46:1361-1371

Ganzhorn JU, Hartum M (2000) Food selection by beaver (Castor fiber albicus) in relation to plant chemicals and possible effects of flooding on food quality. J Zool, Lond 251:391-398

Gosling LM, Baker SJ (1989) The eradication of muskrats and coypus from Britain. Biol J Linn Soc 38:39-51

Guichón ML, Benitez VB, Abba A, Borgnia M, Cassini MH (2003) Foraging behaviour of coypus Myocastor coypus: why do coypus consume aquatic plants? Acta Oecol 24:241-246

Halley DJ, Rosell F (2002) The beaver's reconquest of Eurasia: status, population development and management of a conservation success. Mamm Rev 32:153-178 
Hanson JM, Mackay WC, Prepas EE (1989) Effect of size-selective predation by muskrats (Ondatra zibethicus) on a population of unionid clams (Anodontas grandis simpsoniana). J Anim Ecol 58:15-28

Higgins C, Mitsch WJ (2001) The role of muskrats (Ondatra zibethicus) as ecosystem engineers in created freshwater marshes. Annu Rep Olentangy River Wetland Res Park:81-86

IUCN (1999) IUCN guidelines for the prevention of biodiversity loss due to biological invasion. Species 31-32:28-42

Johnson LA, Foote LA (1997) Vertebrate herbivory in managed coastal wetlands: a manipulative experiment. Aquat Bot 59:17-32

Jouventin P, Micol T, Verheyden C, Guédon G (1996) Le ragondinbiologie et méthodes de limitation des populations. Acta, Paris

Kolar CS, Lodge DM (2001) Progress in invasion biology: predicting invaders. Trends Ecol Evol 16:199-204

Le Louarn H, Quéré J-P (2003) Les rongeurs de France-Faunistique et biologie, 2nd edn. INRA, Paris, France

Leau W, Léger F (2006) Situation actuelle de l'aire de répartition du castor d'Europe (Castor fiber) sur les bassins versants SeineNormandie, Rhin-Meuse et haut bassin de la Saône. Office National de la Chasse et de la Faune Sauvage, Direction des Etudes et de la Recherche, Gerstheim, France

Lees AC, Bell DJ (2008) A conservation paradox for the 21st century: the European wild rabbit Oryctolagus cuniculus, an invasive alien and an endangered native species. Mamm Rev 38(4):304320

Léger F (2007) Notes sur la présence du ragondin (Myocastor coypus) dans le département des Ardennes. ONCFS, CNERA animaux prédateurs et déprédateurs, Gerstheim, France, pp 1-5

Libois R (2006) Les mammifères non volants de la Région Wallonne: tendances des populations. Dossier scientifique réalisé dans le cadre de l'élaboration du Rapport analytique 2006 sur l'Etat de l'Environnement wallon. Unités de Recherches zoogéographiques, Université de Liège:1-127

Lorvelec O, Pascal M (2005) French attempts to eradicate nonindigenous mammals and their consequences for native biota. Biol Invasions 7:135-140

Lowe S, Browne M, Boudjelas S, De Poorter M (2000) 100 of the world's worst invasive alien species. A selection from the global invasive species database. ISSG, SSC and IUCN, Auckland, New Zealand

Macdonald DW, Tattersall FHS, Brown ED, Balharry D (1995) Reintroducing the European beaver to Britain: nostalgic meddling or restoring biodiversity? Mamm Rev 25:161-200

Macdonald DW, Tattersall FHS, Rushton S, South AB, Rao S, Maitland P, Strachan R (2000) Reintroducing the beaver (Castor fiber) to Scotland: a protocol for identifying and assessing suitable release sites. Anim Conserv 3:125-133

Mack RN, Simberloff D, Lonsdale WM, Evans H, Clout M, Bazzaz FA (2000) Biotic invasions: causes, epidemiology, global consequences, and control. Ecol Appl 10:689-710

Manchester SJ, Bullock JM (2000) The impact of non-native species on UK biodiversity and the effectiveness of control. J Appl Ecol $37: 845-864$

Maringer A, Slotta-Bachmayr L (2006) A GIS-based habitatsuitability model as a tool for the management of beavers Castor fiber. Acta Theriol 51:373-382

McDonald RA, O'Hara K, Morrish DJ (2007) Decline of invasive alien mink (Mustela vison) is concurrent with recovery of native otters (Lutra lutra). Divers Distrib 13:92-98

Messier F, Virgl J (1992) Differential use of bank burrows and lodges by muskrats, Ondatra zibethicus, in a northern marsh environment. Can J Zool 70:1180-1184

Messier F, Virgl JA, Marinelli L (1990) Density-dependent habitat selection in muskrats: a test of the ideal free distribution model. Oecologia 84:380-385
Müller-Schwarze D, Sun L (2003) The beaver, natural history of a wetland engineer. Cornell University Press, Ithaca, NY

Nadeau S, Décarie R, Lambert D, St-Georges M (1995) Nonlinear modeling of muskrat use habitat. J Wildl Manage 59:110 117

Nolet BA, Rosell F (1998) Comeback of the beaver Castor fiber: an overview of old and new conservation problems. Biol Conserv $83: 165-173$

Nolet BA, Hoekstra A, Ottenheim MM (1994) Selective foraging on woody species by the beaver Castor fiber, and its impact on a riparian willow forest. Biol Conserv 70:117-128

Nummi P, Väänänen V-M, Malinen J (2006) Alien grazing: indirect effects of muskrats on invertebrates. Biol Invasions 8:993-999

Panzacchi M, Bertolino S, Cocchi R, Genovesi P (2007) Population control of coypu Myocastor coypus in Italy compared to eradication in UK: a cost benefit analysis. Wildl Biol 13:159171

Parker K (2008) Translocations: providing outcomes for wildlife, resource managers, scientists, and the human community. Restor Ecol 16:204-209

Pascal M, Lorvelec O, Vigne J-D (2006) Invasions Biologiques et Extinctions: 11000 ans d'histoire des Vertébrés en France. Coédition Belin, Quæ, Paris

Pieret N, Delbart E, Vanderhoeven S, Mahy G (2008) Invasive plant species management tests and advices along river banks in the Walloon region. 6th European Conference on Ecological Restoration, 8-12 September, Ghent, Belgium

Prigioni C, Balestrieri A, Remonti L (2005) Food habits of the coypu, Myocastor coypus, and its impact on aquatic vegetation in a freshwater habitat of NW Italy. Folia Zool $54: 269-277$

Richardson DM, Pysek P, Rejmanek M, Barbour MG, Panetta FD, West CJ (2000) Naturalization and invasion of alien plants: concepts and definitions. Divers Distrib 6:93-107

Rosell F, Bjørkøyli T (2002) A test of the dear enemy phenomenon in the Eurasian beaver. Anim Behav 63:1-6

Rosell F, Bergan F, Parker H (1998) Scent-marking in the Eurasian beaver (Castor fiber) as a mean of territory defense. J Chem Ecol 24(2):207-219

Rosell F, Bozsér O, Collen P, Parker H (2005) Ecological impact of beavers Castor fiber and Castor canadensis and their ability to modify ecosystems. Mamm Rev 32:248-276

Rosell F, Parker H, Steifetten Ø (2006) Use of dawn and dusk sight observation to determine colony size and family composition in Eurasian beaver Castor fiber. Acta Theriol 51:107-112

Rouland P (1991) La réintroduction du castor en France. Le Courrier de l'Environnement de l'INRA 14:35-42

Schwoerer M-L, Léger F, Allain C (2008) Le plus gros rongeur d'Europe: le Castor. Chasseur de l'Est 10:10-18

Shea K, Chesson P (2002) Community ecology theory as a framework for biological invasions. Trends Ecol Evol 17:170-176

South A, Rushton S, MacDonald D (2000) Simulating the proposed reintroduction of the European beaver (Castor fiber) in Scotland. Biol Conserv 93:103-116

StatXactC (1989-1997) Version 3.1. Cytel Software, Cambridge, UK

Swank WG, Petrides GA (1954) Establishment and food habits of the nutria in Texas. Ecology 35:172-176

Ter Braak JFC (1987) The analysis of vegetation-environment relationships by canonical correspondence analysis. Vegetatio 69:69-77

Ter Braak JFC (1990) CANOCO update notes. Agricultural Mathematics Group, Wageningen

Ter Braak JFC, Verdonschot PFM (1995) Canonical correspondence analysis and related multivariate methods in aquatic ecology. Aquat Sci 57:153-187 
Valéry L, Fritz H, Lefeuvre J-C, Simberloff D (2008) In search of a real definition of the biological invasion phenomenon itself. Biol Invasions 10:1345-1351

Vázquez DP (2002) Multiple effects of introduced mammalian herbivores in a temporal forest. Biol Invasions 4:175-191

Verbeylen G (2002) Coypus (Myocastor coypus) in Flanders: how urgent is their control? Lutra 45:83-96

Véron G (1991) Les castors. Série "Comment vivent-ils?", vol 26. Payot Lausanne:1-32

Wauters LA, Gurnell J, Martinoli A, Tosi G (2002a) Interspecific competition between native Eurasian red squirrels and alien grey squirrels: does resource partitioning occur? Behav Ecol Sociobiol $52: 332-341$
Wauters LA, Tosi G, Gurnell J (2002b) Interspecific competition in the tree squirrels: do introduced grey squirrels (Sciurus carolinensis) deplete tree seeds hoarded by red squirrels $(S$. vulgaris). Behav Ecol Sociobiol 51:360-367

Williamson M (1996) Biological invasions. Chapman \& Hall, London, UK, pp 1-244

Willner GR, Feldhamer GA, Zucker EE, Chapman JA (1980) Ondatra zibethicus. Mamm Species 141:1-8

Woods CA, Contreras L, Willner-Chapman G, Whidden HP (1992) Myocastor coypus. Mamm Species 398:1-8

Wright JP, Jones CG, Flecker AS (2002) An ecosystem engineer, the beaver, increases species richness at the landscape scale. Oecologia 132:96-101 